\title{
ОТЧЕТ БЛАГОЧИННОГО ИРКУТСКОГО УЕЗДА КАК ИСТОРИЧЕСКИЙ ИСТОЧНИК КОНЦА ХІХ ВЕКА
}

В статье анализируются отчетные сведения благочинного 3 участка Иркутского уезда как исторический источник по изучению хозяйственной, религиозно-нравственной жизни церквей и приходов Иркутской епархии в конце XIX в.

Ключевые слова: Иркутская епархия, благочиние, церковь, приход, священник.

S.A. SHALAMOVA

\section{REPORT OF THE DEAN OF THE IRKUTSK DISTRICT AS A HISTORICAL SOURCE OF THE LATE NINETEENTH CENTURY}

The article analyzes the reporting information of the Dean of the 3rd section of the Irkutsk district as a historical source for the study of economic, religious and moral life of churches and parishes of the Irkutsk diocese in the late XIX century.

Keywords: Irkutsk diocese, deanery, church, parish, priest.

В материалах 50 фонда Иркутской духовной консистории Государственного архива Иркутской области отложилась отчетная документация благочинных округов по деятельности церквей и приходов Иркутской епархии за разные периоды. В данном случае внимание будет уделено анализу документов конца XIX в. C момента учреждения в 1727 г. Иркутской епархии управление и духовный суд в ней осуществлялись через духовную консисторию (1746). Управление епархией консистория осуществляла через духовные правления, благочинных и настоятелей монастырей. Помощниками епархиальных архиереев в духовных правлениях являлись приходские священники, или так называемые благочинные, осуществлявшие надзор за благочинием в приходах 10-30 церквей, которые составляли благочиннический округ [4, с. 33].

Следует отметить, что если изначально территория Иркутской епархии была огромной, то в результате образования новых церковных областей: Томской и Енисейской епархии (1834), Якутской (1852) и Забайкальской (1894), в конце XIX века границы Иркутской епархии постепенно сократились и стали соответствовать границам Иркутской губернии. К началу XX в. административные округа (уезды) губернии 
были разделены на благочиннические округа (участки). Первое благочиние находилось в Иркутске и насчитывало 29 церквей.

В Иркутском уезде находилось 3 благочиннических округа, 2 благочиния имелось в Верхоленском уезде, 3 - в Киренском, по 4 - в Балаганском и Нижнеудинском уездах. Кроме того, 3 благочиния объединяли специальные миссионерские церкви Верхоленского, Балаганского уездов, а также Тункинского ведомства Иркутского уезда. В среднем благочиние состояло из 11 церквей, а часовен и молитвенных домов в епархии было 207 [3, с. 140]. К ведению благочиний не относились: Иркутский кафедральный собор, 2 церкви при архиерейском доме и походная церковь на золотых приисках Бирюсинской системы.

Благочинные, обычно в сане протоирея обладали большой властью, если входили в состав консистории. Один раз в полгода они объезжали церкви своего округа, писали рапорты, доклады, отчеты, донесения и др., которые подавали на рассмотрение и утверждение в консисторию. По отчетным сведениям благочинных можно судить о хозяйственном, финансовом, религиозно-нравственном состоянии благочиний в округах, о деятельности духовенства на местах, о взаимоотношениях с консисторией, о роли религии в жизни прихожан.

Следует отметить, что в 1862 г. из состава консистории благочинные были исключены, а вместе с ними было «устранено справедливое негодование иркутского духовенства, которые видели в благочинных и обвинителя и судью, а суд консистории в большинстве своем был на стороне благочинного, как ее сочлена, имевшего голос в собственном деле» [3, с. 139]. Именно по этой причине, в клировых ведомостях в конце XIX - начале XX в. уже не содержится отметок благочинных о поведении членов причта, что сказалось и на отчетных сведениях тоже, так как эти функции с благочинных были сняты.

Анализ отчетных сведений благочинного 3 участка Иркутского уезда протоирея Г. Цветкова показал, что в состав благочиния в 1899 г. входило 13 приходских и 2 приписных церквей [2, л. 1]. Отметим, что в 1897 г. в состав благочиния входило 11 церквей: Больше-Жилкинская Покровская, Больше-Еланская Троицкая, Китойская Христорождественская, Биликтуйская Христорождественская, Тельминская Казанская, Усольская Спасская, Мольтинская Вознесенская, Бадайская Николаевская, Тайтурская Петропавловская, Узколугская Троицкая, Бархатовская Иоанно-Прокопьевская [1, с. 7-8].

Также в документе дана характеристика благоустройства и церковного хозяйства благочиния. В отчете отмечаются сведения о строительстве новых церквей и ремонте ветхих. В 1899 г. в благочинии имелось 5 каменных церквей из 15, остальные были деревянные, все они отличались достаточной прочностью и благоустроенностью. В отчетном году была окончена кладка каменной колокольни при Мальтинской Вознесен- 
ской церкви, вокруг последней была устроена новая ограда, произведен наружный ремонт церквей: Биликтуйской Христорождественской, Китойской Христорождественской и Бадайской Николаевской. Окончена постройка новой деревянной Покровской церкви в селении Больше-Жилкинском, взамен прежней, ветхой. Есть сведения о часовнях, которых в округе насчитывалось 4, одна из них была с алтарем и в ней 2-3 раза в месяц совершались богослужения [2, л. 8].

В отчетных сведениях благочинных проверяется и оценивается состояние церковного имущества. В документе упоминается, что все храмы 3 участка Иркутского уезда содержались в должной чистоте и порядке, утварью и ризницей были снабжены достаточно, имелось все необходимое для совершения богослужений, за исключением МалоЕланской церкви, где ощущался недостаток в богослужебных книгах. Святые антиминсы были прочными и чистыми. Также благочинный обращает внимание на материальное положение церквей.

В результате ревизии описей церковного и денежного имущества делается вывод об их сохранности и порядке, хищений и растрат не обнаружено. За исключением одного случая, когда в октябре 1899 г. неизвестными злоумышленниками было похищено из Тайтурской Петропавловской церкви около 140 р. деньгами. При осмотре приходо-расходных книг нарушений также не было выявлено, книги велись исправно и своевременно, ежемесячно производилась проверка церковных сумм в присутствии причта, старосты и доверенных от прихожан. Итоговая проверка церковной документации показала, что в ведении, оформлении метрических книг, книг брачных обысков, венчиковых тетрадей, исповедных росписей церквей особых нарушений не обнаружено.

Оценивается и материальное обеспечение духовенства. Отмечается, что в 1899 г. духовенство 3 участка Иркутского уезда не имело высоких доходов от казны и прихожан. Например, священник получал от 600-1000 р. в год, дьякон от 400-500 р., псаломщики от 200-300 р., что при дороговизне продуктов и товаров первой необходимости того времени, было крайне недостаточно для нормальной жизни. В отличие от городских членов причта, сельские священно-церковнослужители получали от прихожан ругу в виде хлеба, пользовались сенокосной землей и отоплением домов. Однако это не спасало сельский причт, особенно многодетных семей от бедноты, лишений и нужды [2, л. 8 об.].

Из отчета видно, что по итогам 1899 г. в благочинии действовало 9 церковно-приходских школы и 3 школы грамоты, в них обучалось 309 мальчиков и 117 девочек. По социальному составу учителями в этих школах являлись женщины духовного звания, выпускницы епархиального женского училища, которые «знали и любили свое дело и имели успехи в обучении детей» [2, л. 7]. При каждой церкви 3 участка Иркутского уезда имелся также хор певчих, состоявший преимущественно из 
мальчиков и девочек, учеников церковно-приходских школ. И, несмотря на их недостаточную организованность и профессионализм, их пение было полезным, так как привлекало в храм прихожан, родителей хористов [2, л. 2 об.].

Документ раскрывает информацию о наличии и содержании церковных библиотек в округе. Отмечается, что при всех церквях 3 участка Иркутского уезда по итогам проверки 1899 г. имелись библиотеки, которые состояли из книг религиозно-нравственного и исторического содержания, ежегодно пополнявшихся выпиской периодических, духовных журналов с ценными приложениями [2, л. 2]. Автор отчета оценивает степень посещаемости и контингент церковных библиотек, из чего становится ясным, что в основном это были учителя и учащиеся церковно-приходских школ.

Также в задачу благочинного входило изучение статистики проведения богослужений в приходах церквей, проверка богослужебных журналов, досмотр за правильностью исполнения богослужений членами причта. В данном случае, отчетные данные свидетельствуют, что особых нарушений здесь не было выявлено. Богослужение во всех церквях благочиния велось по установленному порядку, в каждый воскресный и праздничный день, а во время великого поста почти ежедневно, только в будние дни богослужение в сельских храмах совершалось по просьбе прихожан для поминовения усопших родственников.

Отчетная документация благочинных дает информацию о состоянии благочестия в приходах округов. Позволяет понять взаимоотношения народа и власти, отношение верующих к религии, к священникам, оценить уровень морально-нравственного развития прихожан. Проводя ревизию, благочинный надзирал за соблюдением порядка в проведении церковных служб, при исполнении треб, отмечал имеющиеся нарушения и требовал их исправления от нарушителей. Из отчетного документа видно, что в пределах благочиния 3 участка Иркутского уезда в пропаганде истин христианской веры среди местного населения, в организации церковных проповедей, религиозно-нравственных чтений, наставлений, нравоучений проблем не было выявлено. Скорее наоборот, народ живет с глубокой внутренней верой, приобщается к ней, ищет в ней утешение, защиту, помощь, особенно крестьяне, которые составляют основную массу прихожан и связаны с землей [2, л. 4].

Религиозно-нравственные наставления по воскресным и праздничным дням в церквях, по-видимому, пользовались большим интересом у публики, оказывали положительное влияние на ее моральный облик и способствовали, если не искоренению, то сглаживанию существующих пороков и недостатков. Успехов в этом отношении в церквях Иркутского уезда достигли священники: Бадайской, Усольской, Тайтурской и Больше-Жилкинской церквей [2, л. 3]. Они практиковали внебогослужебные 
собеседования с прихожанами, что способствовало более разумному проведению досуга в праздничные дни, отвлекало от посещений кабаков, картежной игры, ссор, драк и раздоров. При этом замечено, что «при всей любви верующих к Богу, ввиду неграмотности, невежества, под влиянием чувств эти самые верующие совершали страшные преступления, которые приводили в ужас» [2, л. 5].

Но, несмотря на отсутствие «правильного и ясного понимания главных истин христианского вероучения» прихожанами, они хорошо знают и искренне понимают, что вера в Бога необходима, она спасает, защищает, дает силы, исцеляет, помогает быть добрее, человечнее и сильнее [2, л. 3 об.].

Среди прихожан бытуют поговорки «Больше Бога не будешь», «за Богом молитва, за царем служба не пропадут», что тоже служит свидетельством их веры в Бога. Что касается повседневных молитв: Богородице Деве, Отче наш, краткое славословие Святой Троице, то их знают все прихожане, не знающих их почти нет. Бытует общий христианский обычай молиться утром, вечером, до и после принятия пищи, при входе в дом. Однако эта домашняя молитва совершается прихожанами большей частью по привычке рассеянно и не внимательно. Нередко во время молитвы верующий мог обратиться к членам семьи с вопросами, замечаниями бытового характера, тем самым отвлекаясь от молитвы и мешая другим. Вероятно, православная вера занимала важное место в жизни прихожан, но не определяющее.

Характеризуя отношение прихожан к церковному богослужению, благочинные обращались к анализу богослужебных журналов, ведомостей лиц бывших и не бывших на исповеди и Святого причастия, исповедных росписей. Из отчетных сведений известно, что богослужения в церквях и приходах 3 участка Иркутского уезда проводились своевременно, особенно людными были храмы в воскресные, праздничные дни и в зимнее время. При посещении храма большинство прихожан считали своим долгом принести подношение Богу в виде свечки, или копейки на украшение храма, а зачастую просили священников провести литургию за упокой усопших родственников. Такие литургии в 1899 г. были проведены в следующих церквях: Тельминской около 100, Усольской около 80, Больше-Жилкинской, Бадайской, Больше-Еланской до 40 в каждой, в других приходах меньше [2, л. 5 об.].

При проверке исповедных росписей было зафиксировано, что по итогам прошедшего 1899 г. в Усольском, Узко-Лугском, Тельминском приходах, которые были более многочисленными по количеству жителей, имели меньший процент говевших и исповедовавшихся, чуть более 1/3 прихожан, также в них насчитывалось довольно большое количество лиц от 5-15 лет, не бывших у исповеди и Святого причастия. Аналогичная картина наблюдалась в Тайтурском, Бархатовском и Биликтуйском приходах. 
Примером им были приходы: Больше-Еланский, Больше-Жилкинский и Бадайский, где почти не было лиц не исповедовавшихся, а говевших было очень много. Причинами нестабильного процента говевших и бывших на исповеди, по мнению благочинного, являлись хозяйственная деятельность прихожан, их беспечность, возможный недосмотр самих пастырей [2, л. 6].

Из отчета благочинного можно почерпнуть информацию об отношении прихожан к соблюдению постов. Было замечено, что посты соблюдают не все прихожане, склонность к нарушению постов имеют в основном мужчины, которые часто отлучаются из дома на заработки. Но, Великий пост деревенские жители соблюдают строго. Интересны заметки благочинного по нравственному облику прихожан 3 участка Иркутского уезда. Свои обязательства по отношению к Богу, ближнему, к себе, прихожане, в общем и целом понимают, но в жизни все иначе. Пьянство в праздничный день, по случаю торжества не считается грехом, а наоборот исполнением какого-то долга, обман ближнего, тоже не грех, если его не заметили и не распознали.

Семейные добродетели и ценности: любовь и уважение к родителям, супружеская верность прихожанами соблюдается строго. Поговорка: «Бьет, значит - любит» бытует среди женского населения и считается вполне допустимым явлением в деревенских семьях. Среди прихожан высока степень братской помощи, взаимовыручки в трудную минуту, будь то одолжение денег, хлеба и др. Жители достаточно гостеприимны, отзывчивы, человеколюбивы всегда помогут нуждающимся, обеспечат едой, одеждой, устроят временный приют. Но, в то же время замечено, что в приходах благочиния преобладают такие пороки, как пьянство и сквернословие, с которыми, по возможности, пытаются бороться пастыри. Но, так как основная масса прихожан безграмотна и суеверна, то здесь есть о чем подумать и еще многое предстоит сделать.

Отчетные сведения дают представление об отношении прихожан к духовенству, из чего следует, что эти отношения в основном были почтительными и доброжелательными. Все это было результатом добропорядочного образа жизни и службы большинства членов причта. Также отмечена бесцельность существования приходских попечительств во всех церквях округа, которые существуют только на бумаге, а в реальности никакой помощи прихожанам не оказывают.

При характеристике прихода уделяется внимание другим верованиям. Отмечено, что раскольников было крайне мало в округе, они проживали в приходе Усольской Спасской церкви и, по-видимому, вредного влияния на православных не оказывали. В приходе Тайтурской Петропавловской церкви субботники составляли 105 душ м.п. и 95 душ ж.п., в приходе Китойской церкви, просвещенные святым крещением инородцы язычники, насчитывали в 1899 г. 4 человека. 
Из всего вышесказанного, следует, что отчетная документация благочинного церквей Иркутского уезда является важным историческим источником для изучения жизни церквей и приходов в дореволюционный период. Анализ документа раскрывает роль благочинного в системе церковного управления на местах, определяет специфику его работы. Отчетные сведения позволяют охарактеризовать состояние церковного хозяйства и благоустройства в благочинии, выяснить материальное положение приходов и причта, понять взаимоотношения духовенства и прихожан, оценить роль религии в их жизни. Все это не маловажно для понимания внутренних процессов, которые происходили в православной церкви на рубеже конца $X X$ - начала $X X$ в. и в Иркутской епархии в целом.

\section{Список использованной литературы и источников}

1. Адрес-календарь личного состава служащих правительственных, общественных и частных учреждений г. Иркутска на 1897-1898 год. - Иркутск : Тип. А. А. Сизых, 1897. - 305 с.

2. Государственный архив Иркутской области. - Ф. 50. - Оп. 1. - Д. 7594.

3. Дулов А. В. Православная церковь в Восточной Сибири в XVII - начале XX вв. / А. В. Дулов, А. П. Санников. - Иркутск : «ИНО-Центр (Информация, наука, образование)», 2006. - Ч. 2. - 324 с.

4. История религиозных учреждений Восточной Сибири: Тематический путеводитель по фондам Государственного архива Иркутской области / сост. Е. А. Луговская. - Иркутск : Изд-во «Оттиск», 2017. - 256 с.

\section{Информация об авторе}

Шаламова Светлана Александровна - кандидат исторических наук, главный архивист Отдела использования документов и работы с обращениями граждан и организаций, Государственный архив Иркутской области, 664047, г. Иркутск, ул. Байкальская, 79; e-mail: Swetlana15x@ya.ru

\section{Author}

Svetlana A. Shalamova - PhD in History, Chief Archivist of Department of Use of Documents and Work with Addresses of Citizens and the Organizations, The State Archive of the Irkutsk Region, 79 Baikalskaya St., 664047, Irkutsk, Russia; e-mail: Swetlana15x@ya.ru 